\title{
Perancangan Sistem Informasi Penggajian Pada PT. Eagle Indo Pharma
}

\author{
Risa \\ Progam Studi Sistem Informasi \\ STMIK Dharma Putra \\ ching2 capricorn@yahoo.co.id
}

\author{
Yakub \\ Fakultas Sains dan Ieknologi \\ Universitas Budhhi Dharma \\ y44kub@yahoo.com
}

\begin{abstract}
Abstrak- PT. Eagle Indo Pharma merupakan salah satu perusahaan yang bergerak dalam bidang farmasi. Perusahaan berada di Jl. Raya Prabu Siliwangi Km 1,1 Desa Alam Jaya, Kec. Jatiuwung Tangerang. Mengikuti perkembangan teknologi informasi yang semakin pesat dan semakin canggih, PT. Eagle Indo Pharma memerlukan sistem penggajian yang dilakukan secara terkomputerisasi sehingga dapat memudahkan dalam pemrosesan dan pengerjaannya. Perancangan proses yang dilakukan dengan menggunakan Data Flow Diagram (DFD), perancangan basis data dengan menggunakan Entity Relationship Diagram (ERD). Perancangan sistem informasi ini menggunakan bahasa pemrograman Visual Basic 6.0, basis data yang digunakan adalah pemrograman Microsoft Access 2007, dan Sistem Operasi Microsoft Windows XP. Perancangan sistem informasi yang baru diharapkan bisa menjadi fasilitas yang berguna bagi perusahaan dalam menjalankan kegiatan penggajian dengan lebih baik dan dapat mencapai tujuan yang telah ditetapkan.
\end{abstract}

Keywords- Penggajian, Perancangan, Sistem Informasi, Terkomputerisasi

\section{Pendahuluan}

Seiring dengan berkembangnya teknologi informasi yang semakin pesat di dalam segala aspek sekarang ini, membuat semua perusahaan atau organisasi dituntut untuk mengimbanginya agar dapat bersaing dengan perusahaan lain. Sistem informasi juga merupakan salah satu bagian penting bagi perusahaan dalam meningkatkan produktifitas. Pengolahan data yang baik akan menghasilkan informasi yang tepat pada saat ini maupun di saat yang akan datang. PT. Eagle Indo Pharma merupakan perusahaan nasional dan juga perusahaan keluarga yang bergerak di bidang farmasi, dengan jumlah pegawai pada bagian produksi sekitar 800 orang sedangkan bagian staff 100 orang.

Permasalahannya hingga sampai saat ini transaksi penggajian masih menggunakan program aplikasi secara manual seperti Microsoft Office 2003, sehingga perusahaan mengalami kesulitan untuk membuat laporan.

Berdasarkan permasalahan yang ada di bagian penggajian diusulkan untuk membuat "Perancangan Sistem Informasi Penggajian Karyawan Pada PT. Eagle Indo Pharma”. Sistem informasi yang berjalan digambarkan dengan model fisik berupa Flowchart, model proses berupa Data Flow Diagram
(DFD), dan model data berupa Entity Relationship Diagram (ERD). Diusulkan juga bahasa pemrograman yang digunakan adalah Visual Basic 6.0, perancangan laporan menggunakan Crystal Report 8.5, dan database menggunakan Microsoft Access 2007.

Tujuan dari perancangan sistem informasi penggajian karyawan ini adalah untuk menghasilkan laporan gaji karyawan, data karyawan secara lengkap, slip gaji yang diperlukan oleh karyawan. Manfaat dari perancangan ini adalah untuk mengontrol seluruh kegiatan penggajian karyawan, data yang ada lebih terjaga, membuat kinerja karyawan menjadi lebih baik, mempermudah user dalam mengoperasikan perancangan sistem informasi ini, serta dapat memberikan informasi yang sesuai dengan kebutuhan pemakai dengan cepat, tepat dan akurat.

\section{TinjauAn PUSTAKA}

\section{A. Sistem, Informasi, Sistem Informasi dan Sistem Informasi Manajemen}

Sistem adalah sekelompok elemen-elemen yang terintegrasi dengan maksud yang sama untuk mencapai suatu tujuan [1]. Informasi didefinisikan sebagai data yang diolah menjadi bentuk yang berguna bagi para pemakainya [2]. Sistem informasi dapat didefinisikan sebagai suatu sistem di dalam suatu organisasi yang merupakan kombinasi dari orang-orang, fasilitas, teknologi, media, prosedur-prosedur dan pengendalian yang ditujukan untuk mendapatkan jalur komunikasi penting, memproses tipe transaksi rutin tertentu, memberi sinyal kepada manajemen dan yang lainnya terhadap kejadian-kejadian internal dan eksternal yang penting dan menyediakan suatu dasar informasi untuk pengambilan keputusan yang cerdik [3]. Sistem informasi manajemen dapat didefinisikan sebagai kumpulan dari interaksi sistem-sistem informasi yang bertanggung jawab mengumpulkan dan mengolah data untuk menyediakan informasi yang berguna untuk semua tingkatan manajemen di dalam kegiatan perencanaan dan pengendalian [3]. Basis data adalah kumpulan dari data yang saling berhubungan satu dengan yang lainnya, tersimpan di perangkat keras komputer dan digunakan perangkat lunak untuk memanipulasinya [3]. 


\section{B. Sistem Penggajian}

Gaji (salary) dapat diartikan pembayaran atas penyerahan jasa yang dilakukan oleh karyawan yang mempunyai jenjang jabatan manager, sedangkan upah pada umumnya merupakan pembayaran atas penyerahan jasa yang dilakukan oleh karyawan pelaksana (buruh). Umunya gaji dibayarkan secara tetap perbulan, sedangkan upah dibayarkan berdasarkan hari kerja, jam kerja, atau jumlah satuan produk yang dihasilkan oleh karyawan. [4].

\section{ANALISA DAN PERANCANGAN Sistem}

\section{A. Analisa Sistem Informasi}

Analisa pada sistem yang berjalan menggunakan document flowchart. Dokument flowchart digunakan untuk menjelaskan sistem perusahaan yang sedang berjalan.

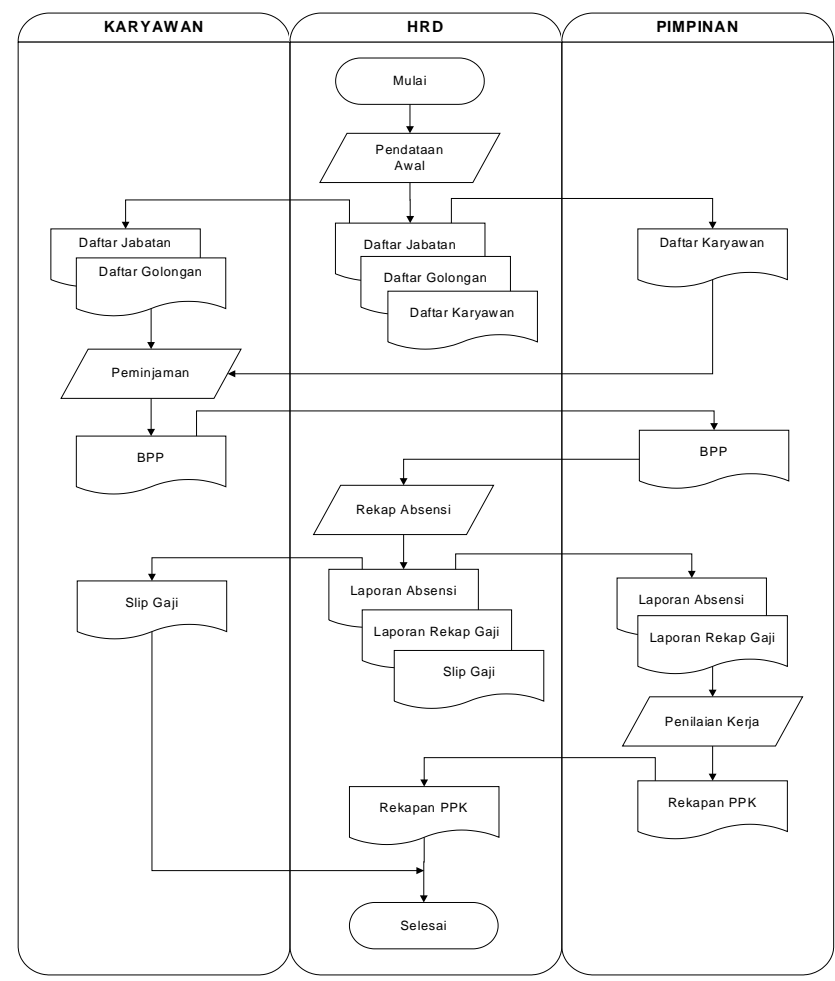

Gambar 1. Dokumen Flowchart Sistem Berjalan pada PT. Eagle Indo Pharma

1) HRD pada PT. Eagle Indo Phrama melakukan proses Pendataan Awal yang kemudian menghasilkan Daftar Jabatan, Daftar Golongan yang diberikan kepada Karyawan dan menghasilkan Daftar Karwayan diberikan kepada Pimpinan.

2) Karyawan melakukan proses Peminjaman yang kemudian mehasilkan BPP (Bukti Pengajuan Peminjaman) yang diberikan kepada Pimpinan.

3) HRD melakukan prose Rekap Absensi yang kemudian menghasilkan Laporan Absensi, Laporan Rekap Gaji yang diberikan kepada Pimpinan dan menghasilkan Slip Gaji diberikan kepada Karyawan.
4) Pimpinan melakukan proses Penilaian Kerja yang kemudian menghasilkan Rekapan PPK (Penilaian Prestasi Kerja) yang diberikan kepada HRD.

\section{B. Perancangan Sistem Informasi}

\section{1) Bagan Berjenjang}

Bagan berjenjang interaksi antara menu-menu untuk membuka form-form yang telah dibuat, dirancang dengan konsep penggolongan dan hirarki. Rancangan Dialog didesain sedemikian rupa untuk memudahkan pemakai.

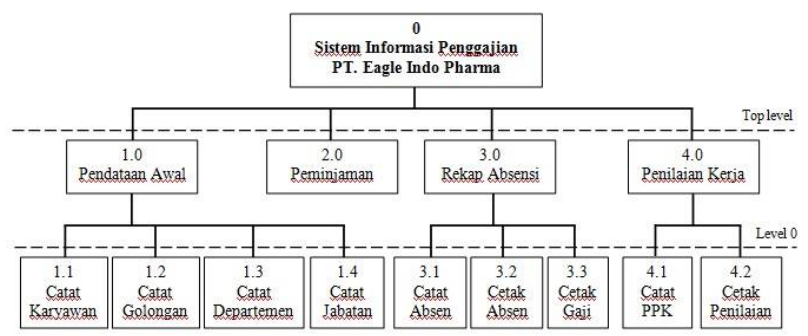

Level 1

Gambar 2. Bagan Berjenjang Sistem Usulan Sistem Informasi Penggajian pada PT. Eagle Indo Pharma

\section{2) Konteks Diagram (Top Level)}

Konteks diagram merupakan awal masukan dan keluaran pada aplikasi penggajian pada PT. Eagle Indo Pharma. Konteks Diagram ini berfungsi menjelaskan alur berjalannya sistem penggajian ini. Entitas yang terlibat antara lain : Pimpinan, HRD, dan Karyawan.

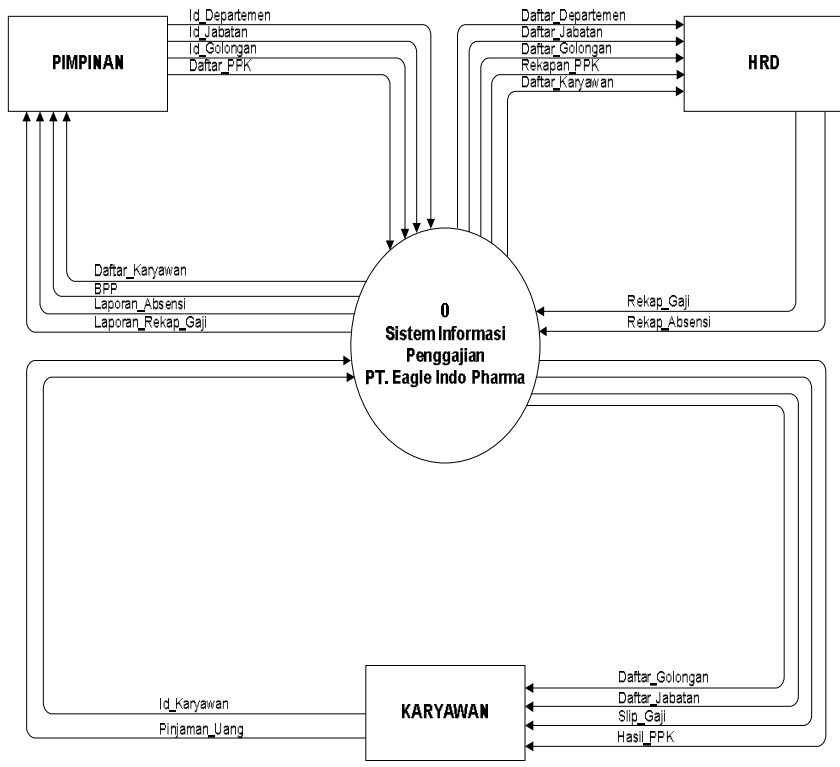

Gambar 3. Konteks Diagram Sistem Usulan Sistem Informasi Penggajian pada PT. Eagle Indo Pharma 
- Pimpinan memberikan input Id_Departemen, Id_Jabatan, Id_Golongan, dan Daftar_PPK dan menerima Daftar_Karyawan, BPP, Laporan_Absensi, dan Laporan_Rekap_Gaji.

- HRD memberikan input Rekap_Gaji dan Rekap_Absensi dan menerima Daftar_Departemen, Daftar_Jabatan, Daftar_Golongan, Rekapan_PPK, dan Daftar_Karyawan.

- Karyawan memberikan input Id_Karyawan, dan Pinjaman_Uang dan menerima Daftar_Golongan, Daftar_Jabatan, Slip_Gaji, dan Hasil_PPK.

\section{3) Diagram Overview (Level 0)}

Diagram overview ini menjelaskan sistem pendataan awal, peminjaman, rekap absensi, dan penilaian kerja. Pada diagram ini dijelaskan data-data yang diterima dan dikeluarkan oleh Pimpinan, HRD, dan Karyawan.

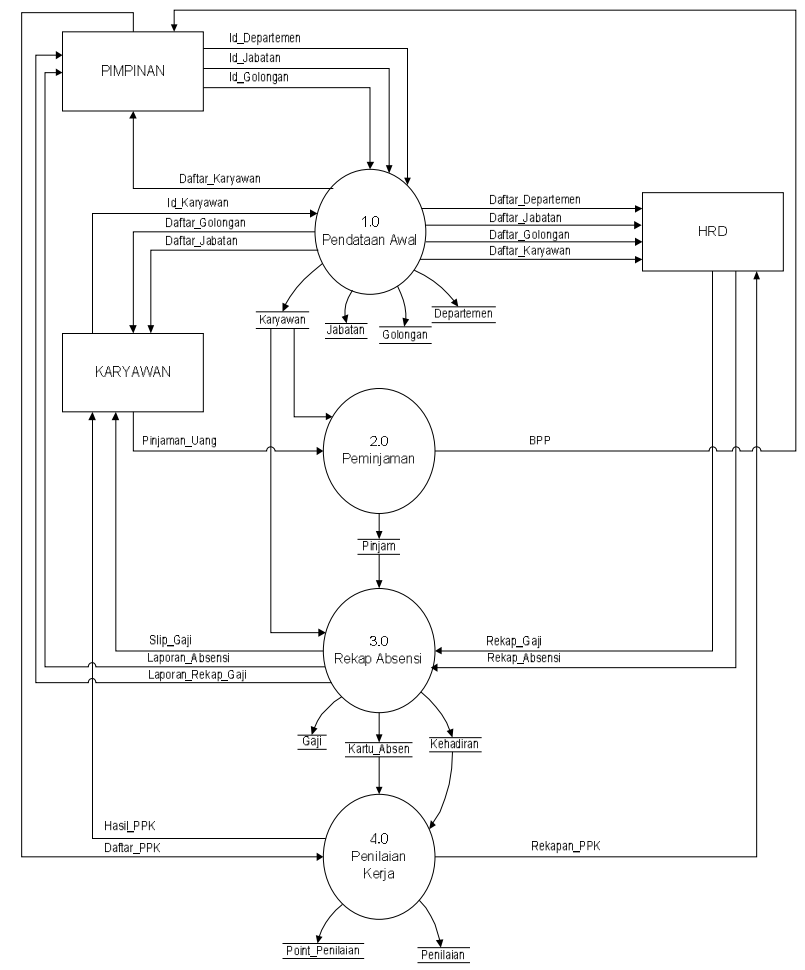

Gambar 4. Diagram Overview Sistem Usulan Sistem Informasi Penggajian pada PT. Eagle Indo Pharma

\section{a) Proses 1 (Pendataan Awal)}

Proses ini dimulai dari pimpinan yang memberikan input Id_Departemen, Id_Jabatan, dan Id_Golongan dan karyawan yang memberikan input Id_Karyawan, dicetak Daftar_Departemen ke HRD, dicetak Daftar_Jabatan dan Daftar_Golongan ke HRD dan ke karyawan, dan Daftar_Karyawan ke HRD dan ke pimpinan, kemudian disimpan pada data store Karyawan, data store Jabatan, data store Golongan, dan data store Departemen.

\section{b) Proses 2 (Peminjaman)}

Proses ini dimulai dari karyawan yang memberikan input Pinjaman_Uang, dibaca data store Karyawan, dicetak BPP ke pimpinan, disimpan pada data store Pinjam.

c) Proses 3 (Rekap Absensi)

Proses ini dimulai dari HRD yang memberikan input Rekap_Gaji dan Rekap_Absensi, dibaca data store Karyawan dan data store Pinjam, dicetak Laporan_Absensi dan Laporan_Rekap_Gaji ke Pimpinan dan dicetak Slip_Gaji ke karyawan, disimpan pada data store Gaji, data store Kartu_Absen, dan data store Kehadiran.

\section{d) Proses 4 (Penilaian Kerja)}

Proses ini dimulai dari pimpinan yang memberikan input Daftar_PPK, dibaca data store Kehadiran dan data store Kartu_Absen, dicetak Hasil_PPK ke karyawan dan dicetak Rekapan_PPK ke HRD, dan disimpan data store Point_Penilaian dan data store Penilaian.

\section{4) Diagram Rinci}

Dalam diagram overview diatas masih ada beberapa proses yang perlu dirinci sehingga proses yang lebih sulit lebih dimengerti. Berdasarkan diagram overview terdapat 3 (tiga) proses yang perlu dirinci, yaitu proses 1, proses 3, dan proses 4. Berikut penjelasan dari masing-masing program sebagai berikut :

\section{a) Diagram Rinci Level 1 (Proses 1)}

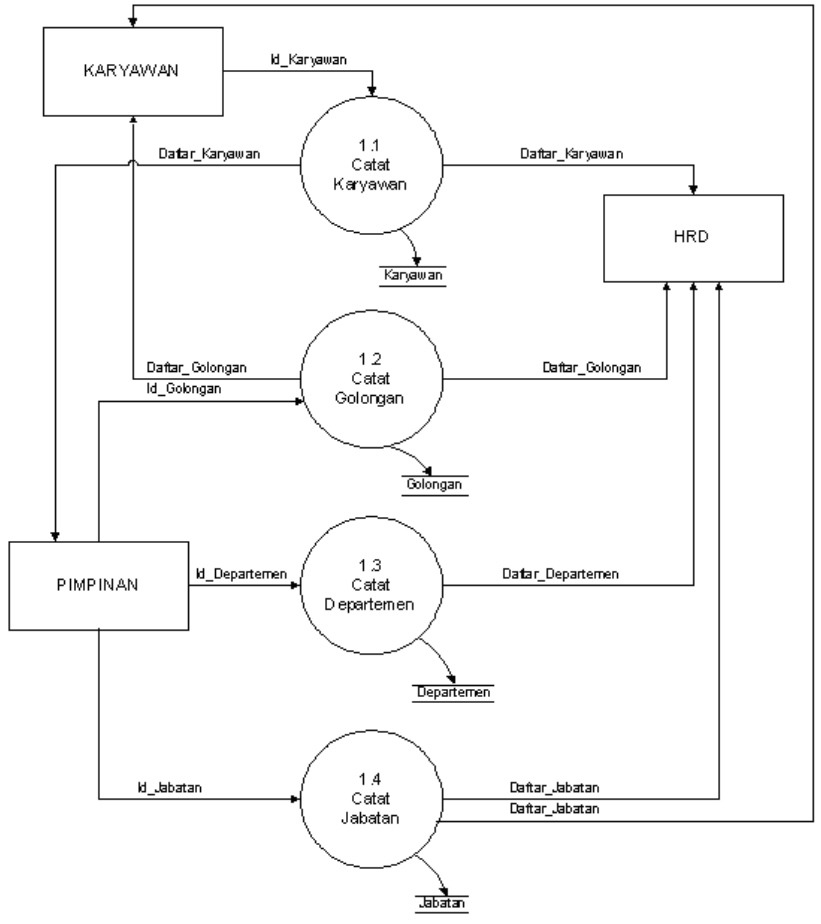

Gambar 5. Diagram Rinci Level 1 (Proses 1) Pendataan Awal 


\section{- Proses 1.1 (Catat Karyawan)}

Pada catat karyawan ini, karyawan memberikan input Id_Karyawan, dicetak Daftar_Karyawan ke HRD dan ke pimpinan, kemudian disimpan pada data store Karyawan.

\section{- Proses 1.2 (Catat Golongan)}

Pada catat golongan ini, pimpinan memberikan input Id_Golongan, dicetak Daftar_Golongan ke karyawan dan ke HRD, kemudian disimpan pada data store Golongan.

- Proses 1.3 (Catat Departemen)

Pada catat departemen ini, pimpinan memberikan input Id_Departemen, dicetak Daftar_Departemen ke HRD, dan disimpan pada data store Departemen.

\section{- Proses 1.4 (Catat Jabatan)}

Pada catat jabatan ini, pimpinan memberikan input Id_Jabatan, dicetak Daftar_Jabatan ke HRD dan ke karyawan, dan disimpan pada data store Jabatan.

\section{b) Diagram Rinci Level 1 (Proses 3)}

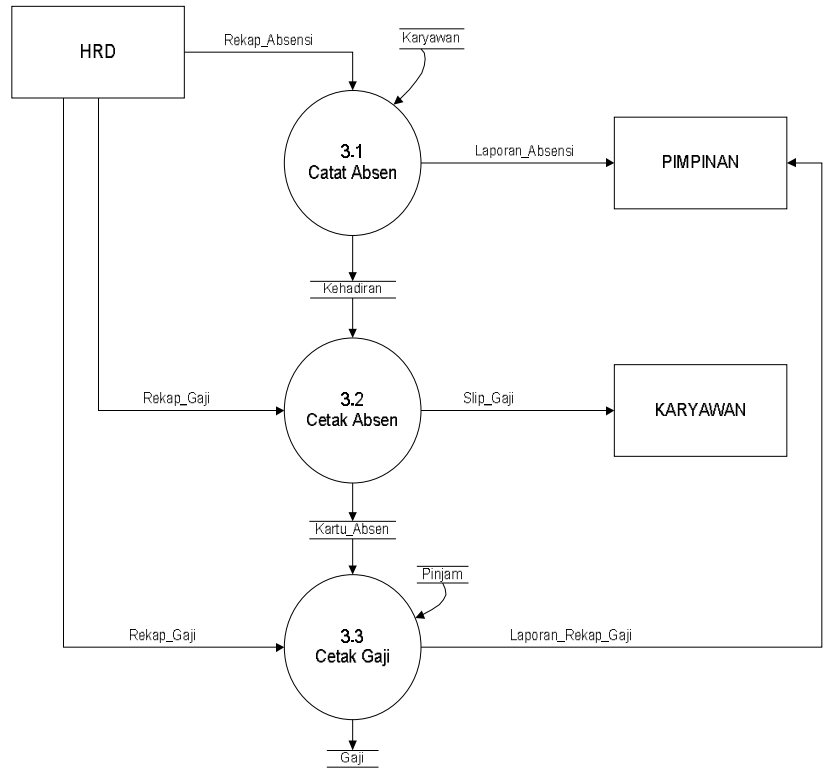

Gambar 6. Diagram Rinci Level 1 (Proses 3) Rekap Absensi

\section{- Proses 3.1 (Catat Absen)}

Pada catat absen ini, HRD memberikan input Rekap_Absensi, dibaca data store Karyawan, dicetak Laporan_Absensi ke pimpinan, dan disimpan pada data store Kehadiran.
- Proses 3.2 (Cetak Absen)

Pada cetak absen ini, HRD memberikan input Rekap_Gaji, dicetak Slip_Gaji ke karyawan, dan disimpan pada data store Kartu_Absen.

- $\quad$ Proses 3.3 (Cetak Gaji)

Pada cetak gaji ini, HRD memberikan input Rekap_Gaji, dibaca data store Pinjam dan data store Kartu_Absen, dicetak Laporan_Rekap_Gaji ke pimpinan, dan disimpan pada data store Gaji.

\section{c) Diagram Rinci Level 1 (Proses 4)}

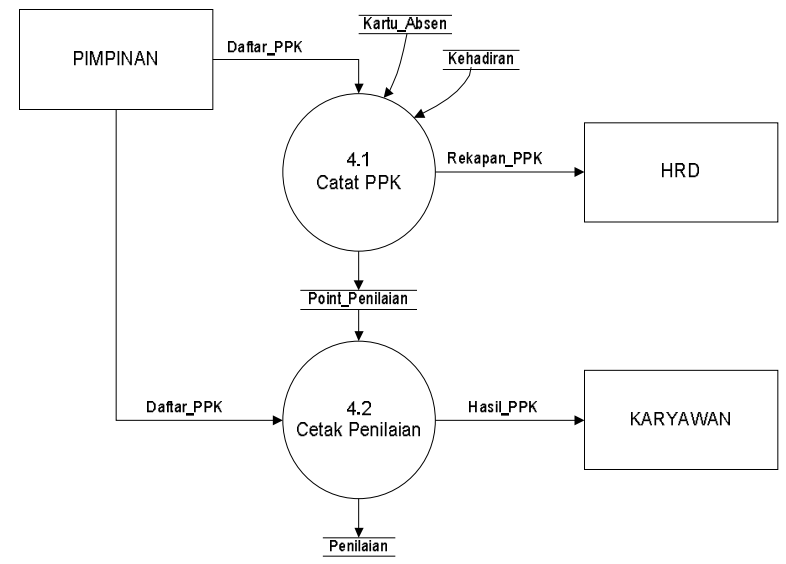

Gambar 7. Diagram Rinci Level 1 (Proses 4) Penilaian Kerja

- $\quad$ Proses 4.1 (Catat PPK)

Pada catat PPK ini, Pimpinan memberikan input Daftar_PPK, dibaca data store Kartu_Absen dan data store Kehadiran, dicetak Rekapan_PPK ke HRD, dan disimpan pada data store Point_Penilaian.

- $\quad$ Proses 4.2 (Cetak Penilaian)

Pada cetak penilaian ini, pimpinan memberikan input Daftar_PPK, dibaca data store Point_Penilaian, dicetak Hasil_PPK ke karyawan, dan disimpan pada data store Penilaian.

\section{Analisa Basis Data}

Analisa Basis Data (Database) yang dibuat untuk menyimpan data-data pada PT. Eagle Indo Pharma. Isi dari database ini adalah tabel-tabel untuk keperluan HRD serta untuk keperluan aplikasi yang dibuat untuk mengelolah penggajian dalam PT. Eagle Indo Pharma. Adapun untuk mendapatkan rancangan basis data yang efektif diperlukan pendekatan sebagai berikut :

\section{1) Entity Relation Diagram (ERD)}

Entity Relation Diagram (ERD) menyatakan bagaimana tabel-tabel yang dihasilkan dari rancangan proses berhubungan satu sama lain. 


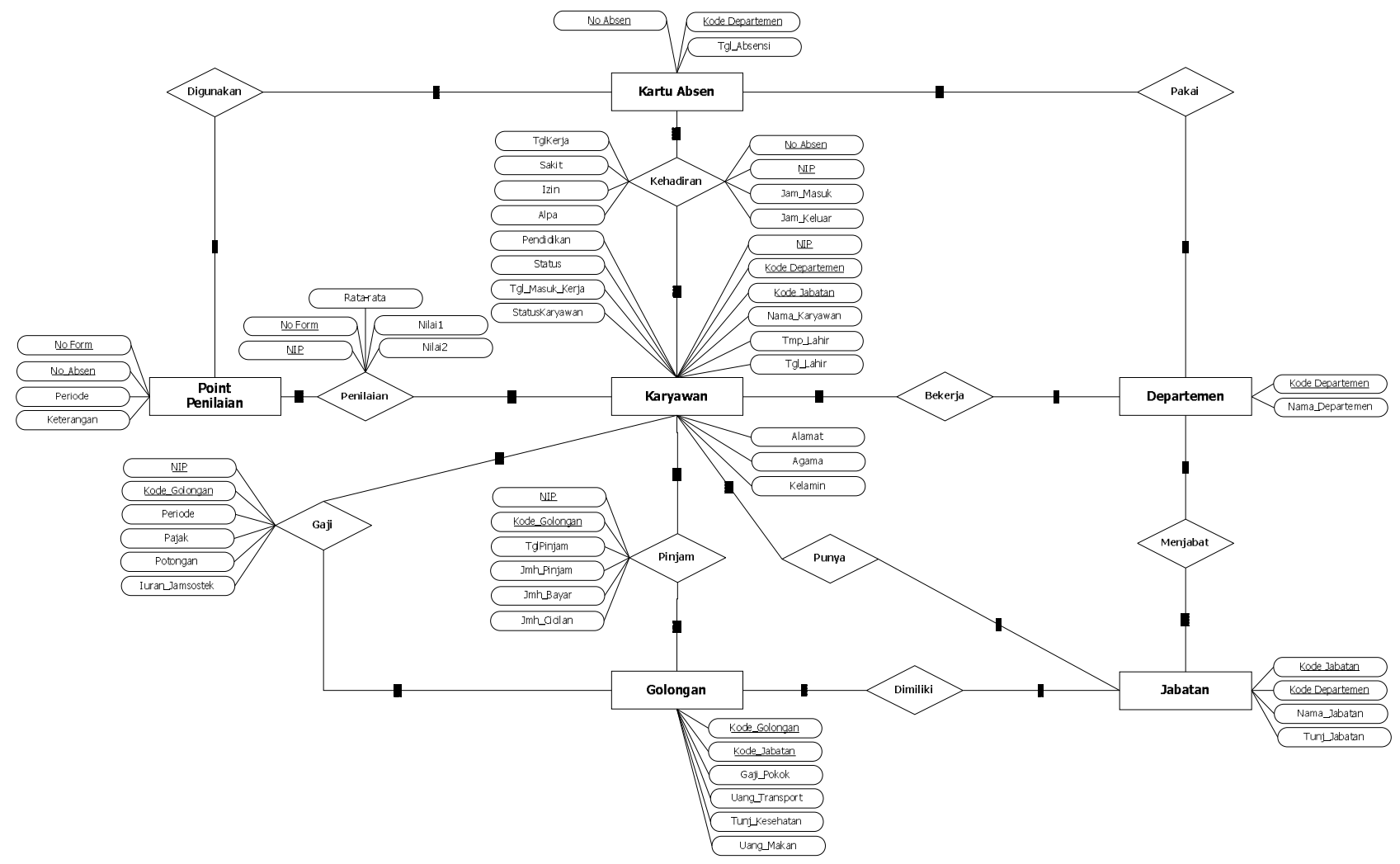

Gambar 8. Entity Relationship Diagram (ERD) Sistem Usulan Sistem Informasi Penggajian

\section{2) Logical Record Structure (LRS)}

Logical Record Structure (LRS) merupakan gambaran hubungan antar record atau tabel yang berbentuk kotak persegi panjang dengan nama yang unik. LRS menyatakan bagaimana tabel-tabel yang dihasilkan dari rancangan proses yang berhubungan satu dengan yang lain.

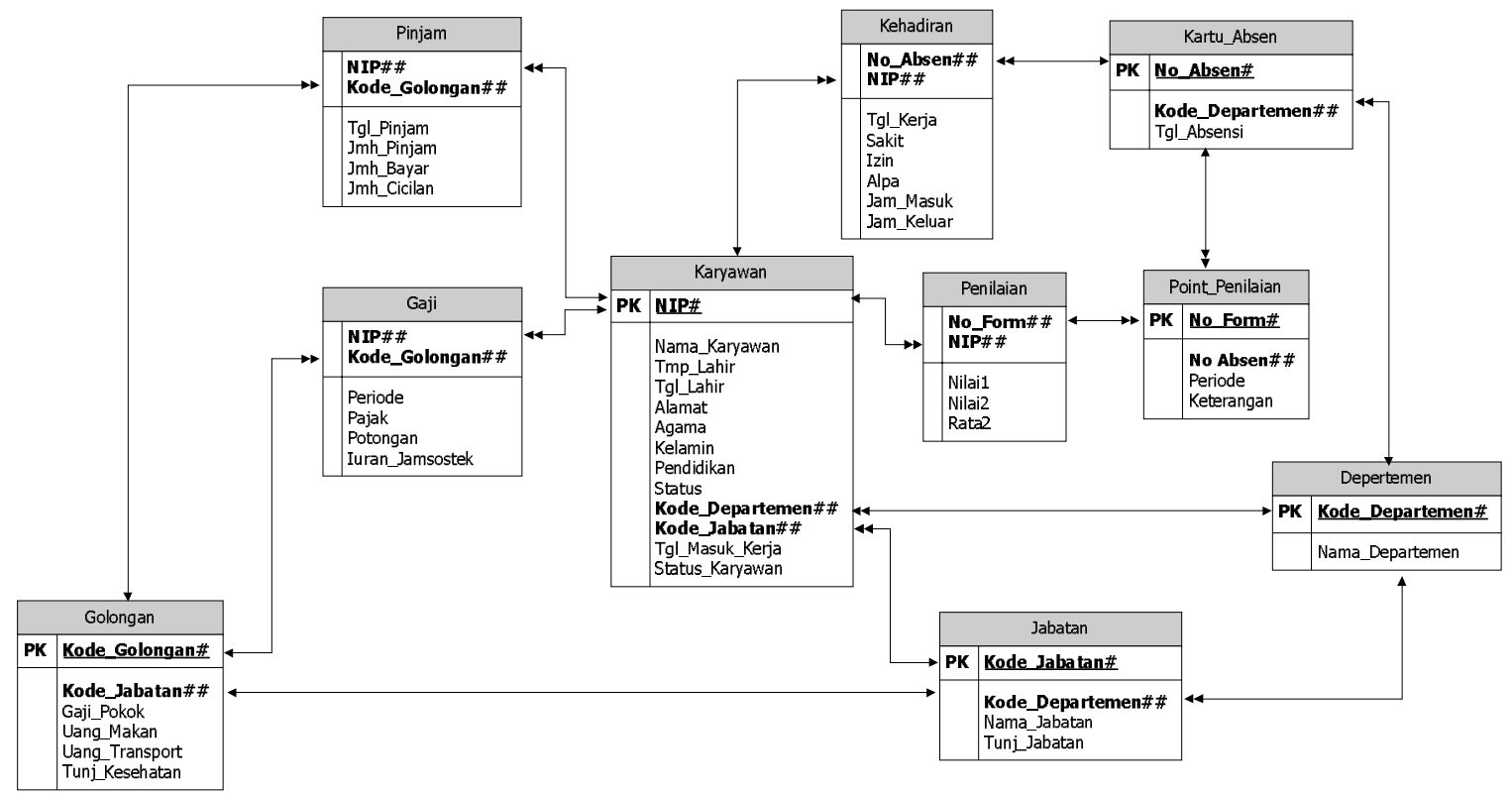

Gambar 9. Logical Record Structure (LRS) Sistem Usulan Sistem Informasi Penggajian 


\section{KESIMPULAN}

Berdasarkan hasil perancangan sistem informasi penggajian pada PT. Eagle Indo Pharma, dapat disimpulkan hal-hal sebagai berikut :

- Dapat menghasilkan data mengenai penggajian yang diperlukan oleh pimpinan, HRD, dan karyawan.

- Menghasilkan data yang lebih akurat dan tepat waktu oleh pimpinan dalam pengambilan keputusan.

- Memberikan kemudahan dalam proses penginputan dan pengontrolan data penggajian.

- Menghasilkan daftar departemen, daftar jabatan, daftar golongan, daftar karyawan, slip gaji, laporan absensi, laporan rekap gaji, dan laporan penilaian prestasi kerja untuk Pimpinan, HRD dan Karyawan.

\section{DAFTAR PUSTAKA}

[1] McLeod Raymon Jr, [2004], Sistem Informasi Manajemen edisi ke delapan, Jakarta:Indeks.

[2] H.M Jogiyanto, [2009], Sistem Teknologi Informasi edisi III Pendekatan Terintegrasi : Konsep Dasar, Teknologi, Aplikasi, Pengembangan, dan Pengelolaan, Jogyakarta:Andi.

[3] H.M Jogiyanto, [2005], Pengenalan Komputer Dasar Ilmu Komputer, Pemrograman, Sistem Informasi dan Intelegensi Buatan, Jogyakarta:Andi.

[4] Mulyadi, [2001], Sistem Akuntansi, Jakarta : Salemba Empat. 